\title{
Sustainable Trail Design, Not Hiker Permits, is Necessary for Environmental Preservation in New York State's Adirondack Park High Peaks
}

\author{
Khang T. Huynh ${ }^{1 *}$, Christopher M. Koudelka ${ }^{2 *}$ \\ ${ }^{1}$ University of Rochester, Department of Biomedical Engineering, Rochester, New York \\ ${ }^{2}$ Finger Lakes Community College, Department of Environmental Conservation and Horticulture, \\ Canandaigua, New York \\ ${ }^{*}$ Authors contributed equally \\ http://doi.org/10.38126/JSPG170111
}

Corresponding author: khuynh2@ur.rochester.edu, ckoudelka@fingerlakes.edu

Keywords: Adirondack Park, High Peaks, soils, sustainable trail design, erosion

\begin{abstract}
Executive Summary: The High Peaks of the Adirondack Park in New York is home to many of the state's precious natural resources and is a favorite destination for hikers. Severe erosion on trails threatens the region's environmental health. Most conservation groups advocate for reducing the number of hikers as the primary solution to combatting erosion; however, the scientific literature indicates that reduction of foot traffic is ineffective at combatting already deteriorating trails. Instead, we recommend the state legislature and Department of Environmental Conservation pursue a plan to rebuild these trails using sustainable design principles, which more effectively ensures their longevity. We outline the research and expertise required to successfully rebuild these trails as well as a mechanism to fund this expensive endeavor.
\end{abstract}

\section{Introduction}

The Adirondack Park, part of New York State's Forest Preserve, is the largest protected forest in the United States. Though home to 130,000 residents, much of the park's 6.1 million acres is kept as undeveloped wilderness. The park's vast diversity of habitats, including lakes, streams, and mountains, provide outdoor recreation to twelve million visitors each year (Adirondack Council n.d.; Adirondack Park Agency 2017). Enshrined in the state constitution is a directive that these lands be "forever kept wild" ("New York State Constitution" 2014).

Within the park is the mountainous High Peaks Wilderness, a premier destination for hikers. This region is home to a 12,000-year-old alpine ecosystem that contains the greatest concentration of rare and endangered species in New York State (Robinson et al. 2010, 355). Twenty-seven species that cover an area of approximately forty acres across 19 High Peaks contribute to the pristine beauty of the summits, provide opportunities to study the
Adirondacks' ecological past, and act as a bellwether for anthropogenic climate change (Goren 2010, 9; Germino 2013, 1-30). Below the alpine zone, the forested slopes provide natural resources such as minerals and timber, and filter the precipitation feeding the region's watersheds.

Erosion, especially on hiking trails, is a major threat to the health of these resources, threatening rare alpine species, polluting the water supply, and tarnishing the immersive experience. As the High Peaks continues to see more hikers, it is easy to conflate this steady (and at some trailheads, exponential) increase with erosion and conclude that hikers are the direct cause of trail deterioration (Adirondack Council Staff 2019). Yet, most studies on soil loss on trails point to properties such as gradient, water drainage features, and surface materials as much better predictors of the rate of soil loss than foot traffic (Cole 1983; Dixon, Hawes, and McPherson 2004, 305-20; Olive and Marion 2009, 1483-93). Poor construction of trails, most of which date back 
to the late 1800s, and trail misuse have jeopardized the health of these fragile natural habitats (Lynch 2016; 2019). The problem has been exacerbated by an uncoordinated plan for maintenance on a meager budget, threatening the state's moral and constitutional duty to protect the health of the Adirondack Park.

Here, we advocate the New York State Legislature to enable the Department of Conservation to rebuild the region's hiking trails using sustainable design techniques. This requires an understanding of the unique characteristics of High Peaks environment that facilitate erosion, paramount to preserving the biodiversity and natural resources in this region. This ambitious project can be funded through a selfsustaining entrance fee. These actions will ensure the longevity of the fragile lands in the High Peaks.

\section{Factors impacting the longevity of High Peaks trails}

\section{i. Current management of High Peaks trails}

The High Peaks Wilderness falls under the jurisdiction of the New York State Department of Conservation (DEC), who are responsible for managing and maintaining the park. Management of the park is outlined in the Adirondack Park State Land Master Plan (APSLMP), as mandated by the Adirondack Park Agency Act of 1971. The current plan, adopted in 1999, identifies various issues with the current hiking trails and offers broad guidelines on maintenance (New York State Department of Environmental Conservation 1999).

Most trails in the High Peaks remain unchanged from when they were first blazed. Hikers sought the most direct paths to the summits and the concept of trail longevity was not considered (Lynch 2016; 2019). These straight-line trails, such as those in Figure 1, fail to avoid dangerous obstacles, and are subject to severe erosion and damage to vegetation. The DEC acknowledges the problems on these legacy trails and identifies the need to repair or reroute them (New York State Department of Environmental Conservation 1999, 143). However, the APSLMP offers very few guidelines on the equipment, data, and personnel needed to reroute a trail; the standards to which they evaluate successfully rehabilitated trails; and the financial resources required to fund these projects. ii. Criteria for sustainable trails

Sustainable trail design refers to practices in trail construction that ensure hiker safety, prevent soil loss from anticipated traffic, facilitate water drainage, and minimize the need for repair (Marion and Wimpey 2017, 46-57). Trails in the High Peaks generally fail to meet these criteria.

\section{Principles of good design include:}

- Routing through soils resistant to erosion. A soil's susceptibility to erosion principally depends on its texture, characterized by its constituent proportion of sand, silt, and clay. Soils containing high proportions of coarse sand resist erosion, while silt and very-fine sand comprise the most erodible soils (Brewer 2012; Wischmeier and Mannering 1969, 135-36; Vermont Environmental Conservation n.d.; Michigan Department of Environment, Great Lakes, and Energy n.d.). Dislodged soil can end up in waterways, disrupting the ecosystem and promoting the growth of harmful pathogens such as Escherichia coli and Giardia lamblia (Marion et al. 2016, 352-62).

- Side-hill trails. Trails should zigzag gradually rather than directly climb a peak. Steep slopes facilitate erosion by channeling snowmelt and precipitation directly down the trail. Furthermore, side-hill trails provide flexibility for trail designers to navigate around dangerous obstacles such as large boulders (Marion and Wimpey 2017, 46-57).

- Proper water drainage. Muddy surfaces incentivize hikers to avoid these obstacles, disrupting the native flora and exposing more soil to erosion. Placing wood or stone barriers across side-hill trails effectively directs water away from exposed trail, limiting soil loss (Marion and Wimpey 2017, 46-57).

- Hardening with crushed gravel. Mixing crushed gravel with native soil hardens trails, increasing their resistance to erosion (Aust, Marion, and Kyle 2005, 23-25). 


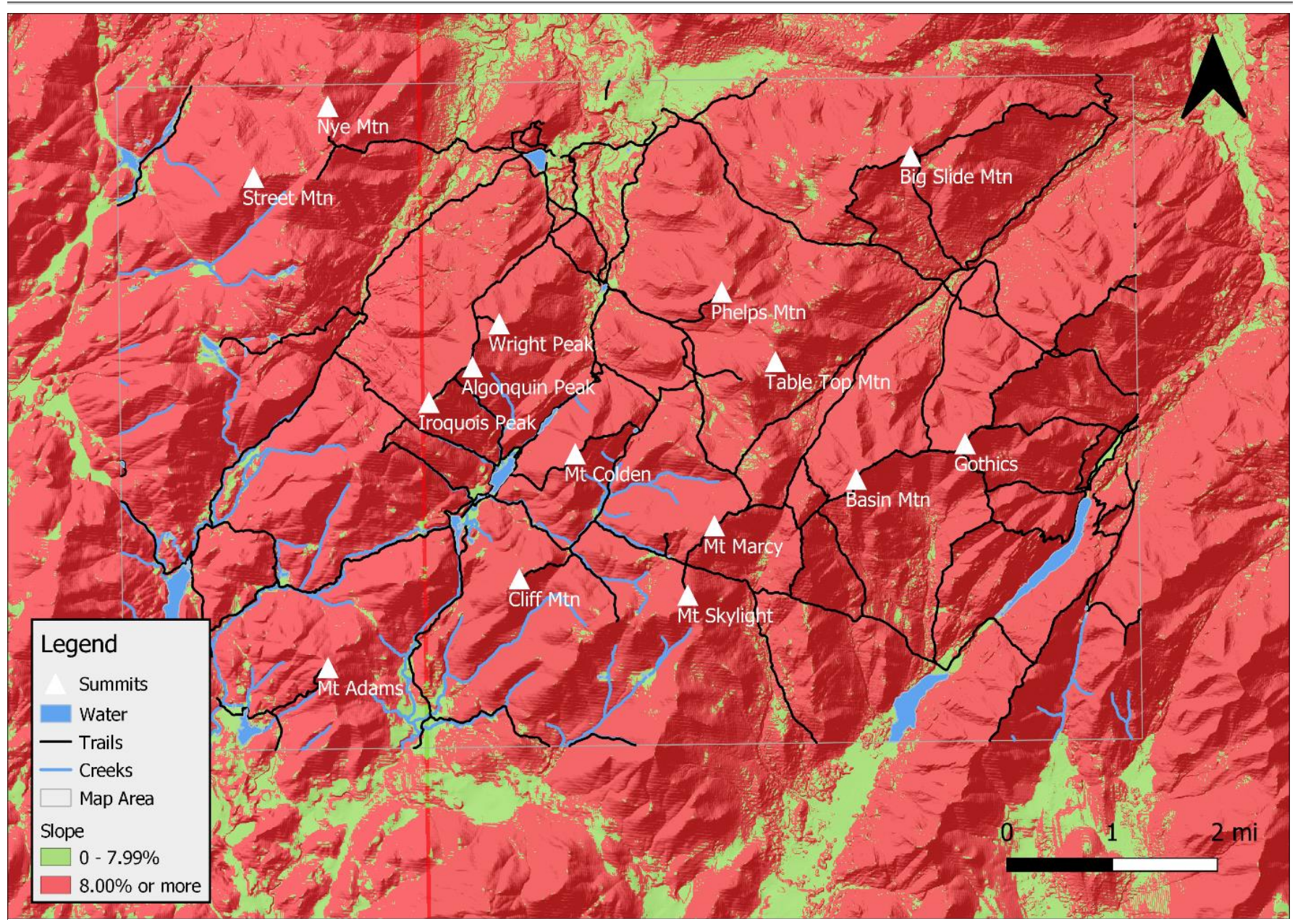

Figure 1. Slope map of the central Adirondack High Peaks. Slopes at or above eight percent, shown in red, exceed the threshold for erosion. Map created using QGIS 3.12 with publicly available sources (U.S. Geological Survey 2019b; 2019a; 2020a; 2020b; Ballston Emergency Management Committee 2018; OpenStreetMap Contributors n.d.).

Most trails in the High Peaks are in desperate need of rerouting and rebuilding. The map of the central High Peaks in Figure 1 shows the slopes of High Peaks trails that exceed an $8 \%$ grade, a commonly accepted threshold for erosion (Marion and Wimpey 2017, 4657). Based on a study done by the Adirondack Council, we estimate 200 miles of trails are unacceptably steep (Lynch 2019; Adirondack Atlas, LLC 2019; Adirondack Council 2019).

This study does not consider efficiency of water drainage, surface materials, soil composition, or locations of dangerous obstacles, suggesting this number is substantially higher. Runoff from these trails may also have contributed to unacceptable levels of Escherichia coli in the waterways near the trails (Ausable River Association n.d.). Furthermore, twenty of the forty-six High Peaks have multiple informal routes haphazardly carved after decades of hiking, that suffer from severe damage to delicate vegetation (see in Figure 1, trails to Table Top and Nye Mountains are not delineated) (Wimpey and Marion 2011, 1012-22; Barros and Marina Pickering 2017, 57-68; Martin and Butler 2017, 354-67). The DEC does not consider these paths as part of the network of trails under its jurisdiction, thus devoting few resources to their maintenance (New York State Department of Environmental Conservation 1999, 72).

Yet, the DEC continues to remedy only their aesthetics, neglecting the underlying problems inherited by these century-old trails. It operates these efforts on a meager budget estimated to be $\sim \$ 87,000$ when adjusted for inflation $(\$ 55,000$ in the 1998 budget published in the APSLMP; the DEC has not published expenditure figures for subsequent years). Much of the work is outsourced to conservation 
groups, who themselves face budgetary and personnel constraints (New York State Department of Environmental Conservation 1999, 98). For example, in 2017, the Adirondack Mountain Club spent $\$ 564,000$ on trail and facility maintenance projects which spanned the entirety of New York State, relied mainly on volunteers, and generally took less than a week (Adirondack Mountain Club 2017). In the High Peaks, trail crews removed fallen trees and installed rock steps on muddy sections (Adirondack Mountain Club 2018; 2019). These actions may discourage hikers from wandering offtrail, but do not aid in drainage or hardening. The approach to trail maintenance taken by the Adirondack Mountain Club and other groups lack the dedicated budget, personnel, and discrete milestones within a master plan required to sufficiently rebuild High Peaks trails.

\section{Proposed policies}

The consensus among Adirondack conservation advocates is that overuse primarily drives trail deterioration and that a permit program to limit the number of hikers is a potential remedy (Levine 2019; Gibson 2019; Amato 2018; Adirondack Mountain Club 2020). Yet most studies on trail conditions suggest that proper trail design contributes more to longevity (Cole 1983; Dixon, Hawes, and McPherson 2004, 305-20; Olive and Marion 2009, 1483-93) than a reduction of visitor traffic (Farrell and Marion 2001, 31-59).

The above observations are supported by commonly accepted principles of trail design. Poor trail design results in trail widening as hikers, avoiding roots and rocks exposed by erosion, seek easier surfaces on which to walk (Hammitt and Cole 1998, 118). Trails that climb steep slopes and fail to divert surface water are subject to accelerated soil erosion with or without visitor use (Hammitt and Cole 1998, 124). Erosion is more distinct in shallow soils, soils high in silt and fine sand, areas with little vegetation cover and areas where concentrated runoff occurs (Hammitt and Cole 1998, 45).

Well-built trails deteriorate minimally over time (Hammitt and Cole 1998, 208), effectively mitigate and manage problems associated with high use (i.e., soil erosion, trail widening), and provide sensitive alpine vegetation with time to recover from trampling (New York State Department of
Environmental Conservation 1999, 44). Methods such trail hardening with gravel to reduce the displacement of small sand and silt particles (New York State Department of Environmental Conservation n.d.; USDA Natural Resources Conservation Service n.d.; Marion and Wimpey 2017, 46-57; Aust, Marion, and Kyle 2005, 14-15) can even protect fine sandy soils in the High Peaks (New York State Department of Environmental Conservation $1999,72)$, which are highly susceptible to erosion. Therefore, sustainable reconstruction of poorly designed trails, rather than a quota on hikers, will more effectively limit erosion in the High Peaks.

Thus, we advocate for the DEC to reroute or rebuild existing trails in accordance with sustainable design principles as the optimal management strategy. A master plan outlined below details the personnel required, the necessary planning for these efforts, and a mechanism through which these projects are funded.

\section{i. Coordinate essential personnel and the public}

The DEC outsources most trail repairs to conservation groups composed mostly of volunteers who lack formal training in sustainable trail design techniques (New York State Department of Environmental Conservation 1999, 144). The requirements of large-scale rerouting projects spanning $>200$ miles of trails necessitate more coordination, planning, and dedication than a few groups of volunteers, though well-intentioned, can provide.

The DEC must gather a team of dedicated, full-time employees that includes:

- Agronomists (soil scientists) to evaluate soil characteristics and water drainage patterns to determine the best routes and develop criteria to prioritize trails

- Surveyors and engineers to ensure paths are designed as side-hill trails

- Full-time trail workers trained in sustainable design techniques

- Construction workers with proper equipment to deliver materials to remote patches of wilderness

Even as it becomes more active in trail rebuilding, the DEC should maintain its partnerships with the public, 
with conservation groups playing an integral role. Volunteer trail crews should work alongside DEC teams in accordance to the latter's priorities and milestones. DEC funding for grants that the Adirondack Mountain Club and others currently receive for trail maintenance (Adirondack Mountain Club 2018; Brosseau 2019) should be increased, with the stipulation that these increases are directed towards fulfilling the DEC's High Peaks trail goals.

Additional outreach activities can continue to foster public-private partnerships through education and engagement. Environmental science students can learn sustainable trail design and construction alongside these professional teams through internship and volunteer opportunities. For the general public, the DEC should incorporate the history of the Adirondacks and trail design demonstrations in its outreach curriculum (New York State Department of Environmental Conservation n.d.). The DEC can even institute a citizen science initiative, encouraging hikers to submit photos and GPS coordinates of waterlogged or eroded sections of trail. This will help ease the burdens of planning and surveying (see next policy proposal).

The time between hiring essential personnel and physical work on trails may be lengthy. Suitable office space, whether in Albany or near the High Peaks, must be acquired. Public hearings and negotiations with conservation groups and other stakeholders are required to organize a list of priorities based on susceptibility. Finally, insurance fees and wages may increase as wilderness work requires traveling to and living in remote, primitive conditions for extended periods of time. Even with these hurdles, a team with the appropriate expertise and driven by clearly defined milestones will more efficiently tackle $>200$ miles of trails than underfunded conservation groups that focus their efforts on short-term projects.

\section{ii. Research environmental factors in the High Peaks that impact trail design}

The DEC must devote appropriate funds and personnel into research of biotic and abiotic factors as a crucial step of trail redesign. Biotic considerations include locating rare alpine species in order to plan routes around them. Interpretation of slope, soil, hydrology, and vegetation data using Geographic Information Systems (GIS) is essential to inform planning decisions for trail work in the region.
Trail design also requires knowledge of abiotic factors in the High Peaks, many of which lack extensive documentation. A systematic study to identify and evaluate proposed trail routes must include factors such as soil properties, drainage patterns, and vegetation. Characterizing soil texture, percent composition of fine sands, and soil permeability on- and off-trails at intervals much finer than those in USDA databases is imperative in determining the most suitable redesign strategy (Wilson and Seney 1994, 78-79; Rangel et al. 2019). During wet seasons, (November 1-December 15; April 1-May 15) (New York State Department of Environmental Conservation 1999, 115), access to trails that experience ponding must be restricted.

Crucially, physical work on a section of a trail cannot commence until these environmental assessments are completed, as the poor resolution of publicly available data is insufficient even for planning. Inclement weather, including heavy snowfall that blankets the region for much of the year ("NY State Average Annual Snowfall Data" n.d.; Adirondack Daily Enterprise Staff 2020), and the presence of hikers in the summer months further inhibit progress. It will take time for the DEC team to determine a threshold for an adequate rate of progress and the optimal number of employees to complete them in a timely manner. Restricting access to trails can facilitate this work at the expense of convenience to some hikers.

\section{iii. Raise revenues through park entrance fees}

The cost of rebuilding the High Peaks trails is estimated to be $\$ 4,000,000$ (approximately $\$ 20,000$ per mile). We estimate the project to span 10 years (20 miles and $\$ 400,000$ per year). The total cost, based on a 2005 study published by the U.S. Forest Service and adjusted for inflation, includes material and labor (Aust, Marion, and Kyle 2005, 15). Salaries for four agronomists and engineers totals $\$ 280,000$ per year, on par with other engineers and biologists hired by the DEC (Department of Environmental Conservation 2018).

To fund these projects, the DEC should charge an entrance fee to visitors entering the High Peaks Wilderness. Despite the Adirondack Park receiving 12.4 million visitors in 2017, the DEC does not impose entrance fees as a mechanism to raise valuable revenues (Adirondack Council n.d.). The number of 


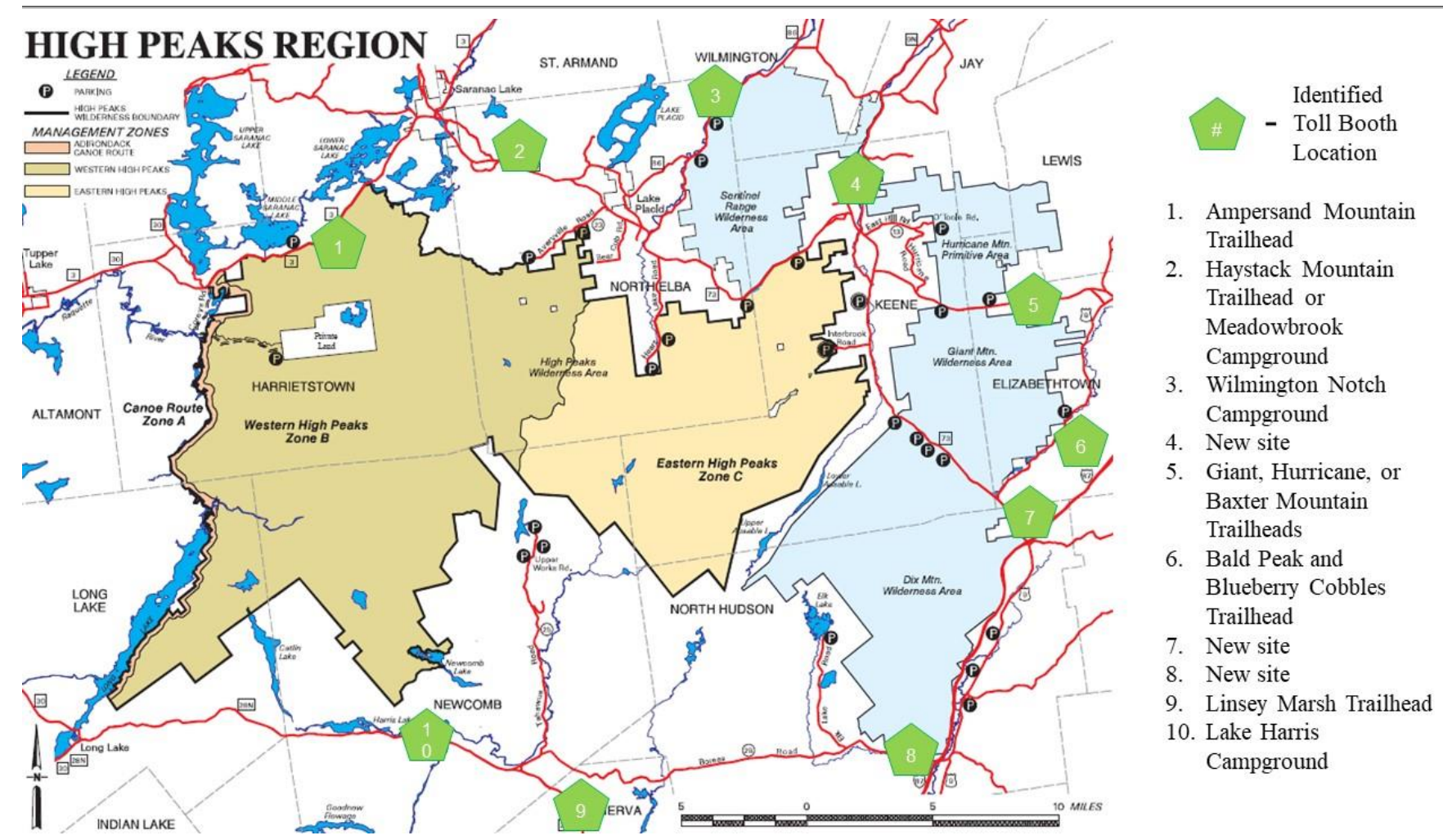

Figure 2. Potential sites for entrance toll booths for the Adirondacks High Peaks. Most locations are by trailheads or campgrounds operated by the DEC, while three new sites need to be acquired. Map altered and published with permission from NYS DEC (New York State Department of Environmental Conservation n.d.).

visitors to the High Peaks was estimated to be $\sim 150,000$ in 1998 (likely to be much higher in 2020, though the DEC has not compiled more recent usage data) (New York State Department of Environmental Conservation 1999, 47; Beier and Larkin 2014).

Most entrances to the High Peaks contain state campgrounds or trailheads near which toll booths can be constructed, with the DEC needing to acquire three new sites (Figure 2). As such, many booth operators can be campground workers, and can be supplemented by 20 additional workers for a total per annum wage of $\$ 600,000$. Construction of each booth is estimated to cost $\$ 10,000$, with an additional $\$ 1,000$ in maintenance costs (Guardian Booth n.d.).

A $\$ 10$ per visit entrance fee would raise the requisite amount of money over 10 years to fund sustainable trails and booths, while providing surplus for conservation efforts in other areas in the park. Stipulating that entrance fees can only be directed towards conservation efforts within the Park creates a self-sufficient revenue stream that circumnavigates potential budgetary squabbles in the state legislature. A park entrance fee is preferable to a hiker permit system, which is more difficult to enforce due to the vastness of the park and remoteness of many trails. Furthermore, the entrance fee seeks to raise revenue for the park without limiting the number of hikers through arbitrary quotas, especially since the number of hikers is not well-documented (New York State Department of Environmental Conservation 1999, 46-49; Beier and Larkin 2014). A similar scheme implemented in White Mountain National Forest in New Hampshire has already been effective, generating \$748,133 from recreation fees in 2017 (USDA Forest Service n.d.; United States Department of Agriculture 2017).

Other indicators suggest the public would be amenable towards this funding strategy. According to a 2018 survey administered by the Adirondack Council to High Peaks hikers, $75 \%$ of hikers support additional funds for the DEC (Adirondack Council 2018). The Council's executive director has expressed a belief that the vast majority of hikers would support paying an access fee for the High Peaks as long as the fees supported trail work (Figura 2019). 
Alternate funding sources for conservation groups that help rebuild trails include the Environmental Protection Fund administered by the Office of Parks, Recreation and Historic Preservation (Parks \& Trails New York n.d.). Rather than allocating $\sim \$ 1.5$ million to fund shuttle busses to trailheads (Adirondack Almanac Editorial Staff 2020), which counters these groups' views against increasing hiker accessibility, funds should be instead dedicated to trail work. It is possible that the proposed entrance fees can be reduced if the shuttle bus funds can be reallocated.

\section{Recommended policy options}

Even though the policies outlined above are designed to be self-sustaining, they require initial investments for the new hires, office space and materials, and construction of the toll booths. As part of the next Fiscal Year Executive Budget passed by the state

\section{References}

Adirondack Almanac Editorial Staff. 2020. "Adirondack Wild: More Trail Crews, Rangers, Test Permit System." The Adirondack Almanack. February 4, 2020.

https://www.adirondackalmanack.com/2020/02 /adirondack-wild-more-trail-crews-rangers-testpermit-system.html.

Adirondack Atlas, LLC. 2019. "Slope Impacts on

Adirondack Trails." 2019.

https://adirondackatlas.org/trail_slopes/.

Adirondack Council. 2018. "2018 Hiker Survey Results

Summary." Adirondack Council. 2018.

https://www.adirondackcouncil.org/page/2018

hiker-surveyresultssummary-276.html.

Adirondack Council. 2019. "Adirondack Hiking Trails

Don't Meet Design Standards." July 2, 2019.

Adironack Council.

https://www.adirondackcouncil.org/page/pressreleases-16/news/adirondack-hiking-trails-dontmeet-design-standards-1219.html.

Adirondack Council. n.d. "About the Adirondack Park." Adirondack Council. Accessed May 10, 2020. https://www.adirondackcouncil.org/page/theadirondack-park-19.html.

Adirondack Council Staff. 2019. “Overuse Degrades Adirondack High Peaks Trails | Redesigning and Rebuilding Trails Can Help Solve Problem." Adirondack Council. May 20, 2019. https://www.adirondackcouncil.org/page/blog$139 /$ news/overuse-degrades-adirondack-highpeaks-trails--redesigning-and-rebuilding-trailscan-help-solve-problem-1166.html. legislature, appropriations to the DEC for the explicit use on High Peaks trail redesign must be made. Once the revenue collection from entrance fees becomes profitable, the DEC must pay back to the state the initial investments.

\section{Conclusions}

The Adirondack High Peaks is home to rare alpine species, an abundance of natural resources, and opportunities for recreation. The State Legislature and the DEC must employ a hands-on conservation plan outlined here with haste. Neglecting our ethical duty to protect the Adirondacks will deprive future New Yorkers the opportunity to appreciate our state's unique ecological history. We must recognize that once these resources disappear, so too will our ability to keep them forever wild.

Adirondack Daily Enterprise Staff. 2020. "DEC Advises of Avalanche Risk in High Peaks.” February 8, 2020. Adirondack Daily Enterprise. https://www.adirondackdailyenterprise.com/ne ws/local-news/2020/02/dec-advises-ofavalanche-risk-in-high-peaks-2/.

Adirondack Mountain Club. 2017. "Form 990." Adirondack Mountain Club. https://www.adk.org/wpcontent/uploads/2018/06/990-for-Distrib2017.pdf.

Adirondack Mountain Club. 2018. “2018 Annual Report Conservation and Advocacy." Adirondack Mountain Club. https://www.adk.org/conservationreport2018/.

Adirondack Mountain Club. 2019. “2019 Trails Report.” Adirondack Mountain Club. https://www.adk.org/wpcontent/uploads/2020/04/Trails-Report2019.pdf.

Adirondack Mountain Club. 2020. "Adirondack Mountain Club, Inc. Conservation Committee Resolution.” Adirondack Mountain Club.

https://www.adk.org/wpcontent/uploads/2020/07/ADK-Resolution-onPermits.pdf.

Adirondack Park Agency. 2017. "Adirondack Park Land Use Classification Statistics - May 25, 2017.” Adirondack Park Agency. May 25, 2017. https://apa.ny.gov/gis/stats/colc201705.htm.

Amato, Christopher. 2018. "Time for Permit System in the High Peaks Wilderness." Adirondack Explorer (blog). June 29, 2018. https://www.adirondackexplorer.org/stories/hi gh-peaks-permit. 
Ausable River Association. n.d. "Adirondack Backcountry Water Testing." Ausable River Association. Accessed May 14, 2020.

https://www.ausableriver.org/programs/waterquality-monitoring/adirondack-backcountrywater-testing.

Aust, Michael, Jeffrey Marion, and Kevin Kyle. 2005.

"Research for the Development of Best

Management Practices to Minimize Horse Trail Impacts on the Hoosier National Forest." U.S. Forest Service.

https://doi.org/10.13140/RG.2.2.21402.95689.

Ballston Emergency Management Committee. 2018.

"Adirondack Park Summits." ESRI. https://hub.arcgis.com/datasets/6b6b21dde1e4 46e3a0326b6c89061dcb 52.

Barros, Agustina, and Catherine Marina Pickering. 2017.

"How Networks of Informal Trails Cause Landscape Level Damage to Vegetation." Environmental Management; New York 60 (1): 57-68. http://dx.doi.org.ezp.lib.rochester.edu/10.1007/ s00267-017-0865-9.

Beier, Colin, and Abigail Larkin. 2014. "Developing an Adirondack Park Trail Register Database to Support Recreation Management and Community Planning." Northeastern States Research Cooperative. May 30, 2014.

https://nsrcforest.org/project/adirondack-parktrail-register-database-supports-recreationmanagement-and-community.

Brewer, James. 2012. "Updates of K Factor, T Factor, and Hydrologic Soil Groups in the Maryland Soils Database." Webinar, February 23.

https://extension.umd.edu/sites/extension.umd. edu/files/docs/programs/anmp/K T HSG Brew er.pdf.

Brosseau, Ben. 2019. "ADK Receives Smart Growth Grant to Improve Heart Lake Program Center Parking, Interpretive Signage." Adirondack Mountain Club (blog). December 11, 2019.

https://www.adk.org/adk-receives-smartgrowth-grant-to-improve-heart-lake-programcenter-parking-interpretive-signage/.

Cole, David N. 1983. "Assessing and Monitoring Backcountry Trail Conditions." United States Department of Agriculture.

http://hdl.handle.net/2027/umn.31951d029659 38y.

Department of Environmental Conservation. 2018. "Careers in Environmental Conservation." Department of Environmental Conservation. April 2018.

https://www.dec.ny.gov/about/571.html.
Dixon, Grant, Martin Hawes, and Glen McPherson. 2004. "Monitoring and Modelling Walking Track Impacts in the Tasmanian Wilderness World Heritage Area, Australia." Journal of Environmental Management 71 (4): 305-20. https://doi.org/10.1016/j.jenvman.2004.02.006.

Farrell, Tracy A., and Jeffrey L. Marion. 2001. "Trail Impacts and Trail Impact Management Related to Visitation at Torres Del Paine National Park, Chile." Leisure/Loisir 26 (1-2): 31-59. https://doi.org/10.1080/14927713.2001.96499 $\underline{28}$.

Figura, David. 2019. "Many Adirondack Mountain Peak Trails Eroding: Who Should Pay to Fix Them?" Newyorkupstate. July 8, 2019. https://www.newyorkupstate.com/outdoors/20 19/07/many-adirondack-mountain-peak-trailshurting-who-should-pay-to-fix-them.html.

Germino, Matthew J. 2013. "Plants in Alpine

Environments." In Ecology and the Environment, edited by Russell K Monson, 1-30. New York, NY: Springer. https://doi.org/10.1007/978-1-46147612-2 12-4.

Gibson, David. 2019. "Time To Reconsider An Old Idea, A High Peaks Permit System -." The Adirondack Almanack. October 6, 2019.

https://www.adirondackalmanack.com/2019/10 La-permit-system-for-the-high-peakswilderness.html.

Goren, Julia. 2010. "Adirondack High Peaks Summit Steward Program." International Journal of Wilderness 16 (2). https://ijw.org/august-2010/.

Guardian Booth. n.d. "Design and Price Your Guard Shack or Ticket Booth In Minutes." Guardian Booth. Accessed July 20, 2020.

https://www.guardianbooth.com/boothpricing/.

Hammitt, William E., and David N. Cole. 1998. Wildland Recreation: Ecology and Management. 2nd ed. John Wiley \& Sons. https://www.wiley.com/enus/Wildland+Recreation $\% 3 \mathrm{~A}+$ Ecology+and+Man agement\%2C+2nd+Edition-p-9780471194613.

Levine, Justin A. 2019. "Permits in the High Peaks?" Adirondack Daily Enterprise, September 28, 2019.

https://www.adirondackdailyenterprise.com/ne ws/local-news/2019/09/permits-in-the-highpeaks/.

Lynch, Mike. 2016. "Adirondack Hiking Trails Show Their Age." The Adirondack Almanack. November 1, 2016.

https://www.adirondackalmanack.com/2016/11 Ladirondack-trails-showing-their-age.html. 
Lynch, Mike. 2019. "Analysis Finds Most High Peaks Trails Fail Design Standards." Adirondack Explorer (blog). July 22, 2019. https://www.adirondackexplorer.org/stories/hi gh-peaks-trails-steepness.

Marion, Jeffrey L., Yu-Fai Leung, Holly Eagleston, and Kaitlin Burroughs. 2016. "A Review and Synthesis of Recreation Ecology Research Findings on Visitor Impacts to Wilderness and Protected Natural Areas." Journal of Forestry; Bethesda 114 (3): 352-62.

http://dx.doi.org.ezp.lib.rochester.edu/10.5849/i of.15-498.

Marion, Jeffrey L., and Jeremy Wimpey. 2017. “Assessing the Influence of Sustainable Trail Design and Maintenance on Soil Loss." Journal of Environmental Management 189 (March): 46-57. https://doi.org/10.1016/j.jenvman.2016.11.074.

Martin, Ross, and David R. Butler. 2017. "A Framework for Understanding Off-Trail Trampling Impacts in Mountain Environments." The George Wright Forum; Hancock 34 (3): 354-67.

Michigan Department of Environment, Great Lakes, and Energy. n.d. "Soils, Erosion, and Runoff." Michigan Department of Environment, Great Lakes, and Energy. Accessed May 31, 2020.

https://www.michigan.gov/documents/deq/wrd -cswo-sesc-manual-unit7 556419 7.pdf.

“New York State Constitution." 2014. New York State Department of State. https://www.dos.ny.gov/info/constitution.htm.

New York State Department of Environmental Conservation. 1999. "High Peaks Wilderness Complex Unit Management Plan: Wilderness Management for the High Peaks of the Adirondack Park." New York State Department of Environmental Conservation.

New York State Department of Environmental Conservation. n.d. "Environmental Education in DEC's Regions 6, 7, and 8." New York State. Accessed July 20, 2020a. https://www.dec.ny.gov/education/93207.html.

New York State Department of Environmental Conservation. n.d. "High Peaks Wilderness Management Zones." New York State. Accessed May 31, 2020b. https://www.dec.ny.gov/outdoor/33889.html.

"NY State Average Annual Snowfall Data." n.d. NY Ski Blog (blog). Accessed July 20, 2020.

https://nyskiblog.com/directory/weatherdata/new-york/state-average-snowfall-map/.
Olive, Nathaniel D., and Jeffrey L. Marion. 2009. "The Influence of Use-Related, Environmental, and Managerial Factors on Soil Loss from Recreational Trails." Journal of Environmental Management 90 (3): 1483-93. https://doi.org/10.1016/i.jenvman.2008.10.004.

OpenStreetMap Contributors. n.d. "OpenStreetMap." OpenStreetMap Foundation. Accessed May 31, 2020.

https://www.openstreetmap.org/export\#map=1 2/44.1467/-73.9376.

Parks \& Trails New York. n.d. "Park \& Trail Partnership Grant." Parks \& Trails New York. Accessed July 20, 2020. https://www.ptny.org/ourwork/support/park-trail-partnership-program.

Rangel, Luana, Maria do Carmo Jorge, Antonio Guerra, and Michael Fullen. 2019. "Soil Erosion and Land Degradation on Trail Systems in Mountainous Areas: Two Case Studies from South-East Brazil." Soil Systems 3 (3): 56. https://doi.org/10.3390/soilsystems3030056.

Robinson, Sean C., Edwin H. Ketchledge, Brian T. Fitzgerald, Dudley J. Raynal, and Robin W. Kimmerer. 2010. "A 23-Year Assessment of Vegetation Composition and Change in the Adirondack Alpine Zone, New York State." Rhodora 112 (952): 355-77. https://doi.org/10.3119/09-03.1.

U.S. Geological Survey. 2019a. "USGS 13 Arc-Second N45w074 1 x 1 Degree." U.S. Geological Survey. https://www.sciencebase.gov/c atalog/item/5deb32fae4b02caea0f0eca7.

U.S. Geological Surve. 2019b. "USGS 13 Arc-Second N45w075 1 x 1 Degree." U.S. Geological Survey. https://www.sciencebase.gov/catalog/item/5de b32fae4b02caea0f0eca9.

U.S. Geological Surve. 2020a. "USGS National Hydrography Dataset Best Resolution (NHD) for Hydrologic Unit (HU) 8 - 03080201 (Published 20200504)." U.S. Geological Survey. https://viewer.nationalmap.gov/basic/.

U.S. Geological Surve. 2020b. "USGS National Hydrography Dataset Best Resolution (NHD) for Hydrologic Unit (HU) 4 - 0202 (Published 20200702)." U.S. Geological Survey. https://www.sciencebase.gov/catalog/item/5a5 8a3a6e4b00b291cd68163.

USDA Forest Service. n.d. "White Mountain National Forest - Recreation Passes \& Permits." Recreation Passes. Accessed August 9, 2020. https://www.fs.usda.gov/detail/whitemountain/ passespermits/recreation/?cid=stelprdb5297292. 
USDA Natural Resources Conservation Service. n.d. "Web Soil Survey." U.S. Department of Agriculture. Accessed May 30, 2020.

https://websoilsurvey.sc.egov.usda.gov/App/Ho mePage.htm.

Vermont Environmental Conservation. n.d. "Soil

Erodibility Evaluation for General Permit 3-9020

Stormwater Runoff From Construction

Activities." Vermont Department of

Environmental Conservation. Accessed May 31, 2020.

https://dec.vermont.gov/sites/dec/files/wsm/st ormwater/docs/StormwaterConstructionDischar gePermits/sw 9020 Erodibility \%20Guidance.pd f.
Wilson, John Paul, and Joseph Seney. 1994. "Erosional Impact Of Hikers, Horses, Motorcycles, And OffRoad Bicycles On Mountain Trails In Montana." Mountain Research and Development 14 (1): 7788. . https://doi.org/10.2307/3673739.

Wimpey, Jeremy, and Jeffrey L. Marion. 2011. "A Spatial Exploration of Informal Trail Networks within Great Falls Park, VA." Journal of Environmental Management 92 (3): 1012-22. https://doi.org/10.1016/j.jenvman.2010.11.015.

Wischmeier, W. H., and J. V. Mannering. 1969. "Relation of Soil Properties to Its Erodibility." Soil Science Society of America Journal 33 (1): 131-37. https://doi.org/10.2136/sssaj1969.0361599500 $\underline{3300010035 x}$.

Khang T. Huynh is a Ph.D. candidate in Biomedical Engineering at the University of Rochester. He is currently developing and using techniques for two-photon adaptive optics scanning light ophthalmoscopy to study function and metabolism in the living retina at a cellular scale. Equally passionate about policy and communication, he is currently a Science Communication Training Fellow with the Association for Research in Vision and Ophthalmology and a Deputy Director for the University of Rochester Science Policy Initiative. Combining his love for classical music and science, Khang founded and directs Science of Music, an outreach ensemble that presents interactive shows and demos throughout the Rochester community. Outside academia, Khang is over halfway through his journey to become an Adirondack 46er, which entails summitting all 46 Adirondacks peaks over 4,000 feet. He received a B.S from The University of Texas at Austin and a M.S. from the University of Rochester.

Christopher M. Koudelka graduated with an A.S. in Environmental Studies from Finger Lakes Community College and plans to attend SUNY ESF for a M.S. related to environmental science. After receiving a B.A. in Peace and Justice from Nazareth College, he attended American University for a certificate in International Peace and Conflict Resolution. He co-presented initial research at the New York State Wetlands Forum on GIS mapping and characterization of vernal pools near Naples N.Y. and mapped invasive plant species in Honeoye N.Y. as part of a management plan with Finger Lakes Partnership in Regional Invasive Species Management (PRISM). His research interests include GIS, land-use change, historic preservation, science and policy, and conflict resolution. For the past four years, he has investigated the history of the former National Guard Float Bridge Rifle Range in Penfield, N.Y., and is currently finishing a book on the subject. In his spare time, Chris enjoys hiking in the High Peaks region.

\section{Acknowledgements}

We would like to acknowledge John Koudelka, M.S., for his assistance on the map design.

\section{Disclaimer}

The authors are members of the Adirondack Mountain Club; however, the views expressed in this memo do not necessarily reflect those of the organization. 